\title{
Phase-lag return mappings for a 3 cell multifunctional central pattern generator
}

\author{
Jeremy Wojcik ${ }^{1,2^{*}}$, Robert Clewley ${ }^{1,2}$, Andrey Shilnikov ${ }^{1,2}$ \\ From Twenty First Annual Computational Neuroscience Meeting: CNS*2012 \\ Decatur, GA, USA. 21-26 July 2012
}

We describe and expand on a novel computational approach to reduce detailed models of central pattern generation to equationless return mapping for the phase lags between the constituting bursting interneurons [1].

Such mappings are then studied geometrically as the model parameters, including coupling properties of inhibitory and excitatory synapses, or external inputs are varied. Bifurcations of the fixed points and invariant circles of the mappings corresponding to various types of rhythmic activity are examined. These changes uncover possible biophysical mechanisms for control and modulation of motor-pattern generation. Our analysis does not require knowledge of the equations that model the system, and so provides a powerful new approach to studying detailed models, applicable to a variety of biological phenomena beyond motor control.

Motifs of three coupled cells are a common network configuration including models of biological central pattern generators. We demonstrate our technique on a motif of three reciprocally coupled, inhibitory and excitatory, cells that is able to produce multiple patterns of bursting rhythms. In particular, we examine the qualitative
(A)

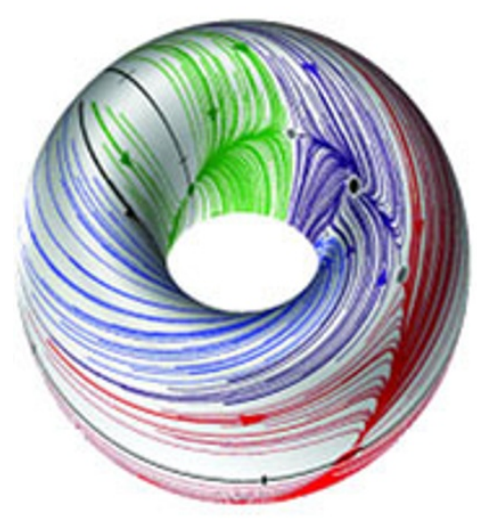

(B)

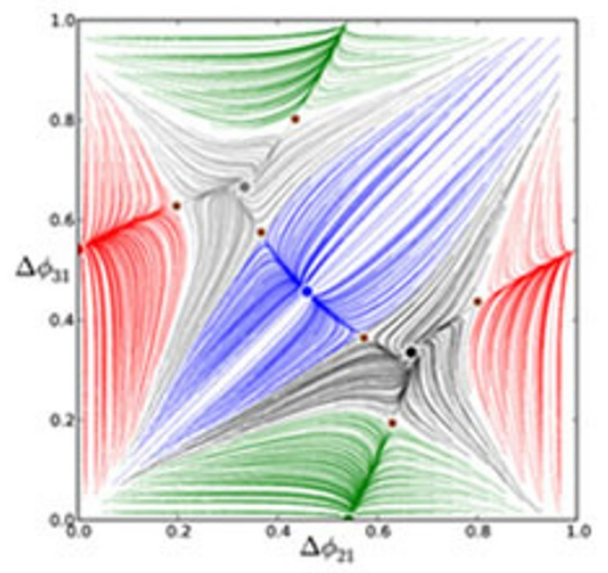

Figure 1 (A). We defined phase-lags for a 3 cell CPG model on a 2D torus. (B) A "flattened" phase-lag mapping showing convergence to 5 distinct attractors. Each stable fixed point represents a rhythmic output of the CPG

\footnotetext{
* Correspondence: jwojcik1@gsu.edu

'Department of Mathematics and Statistics, Georgia State University, Atlanta,

GA 30033, USA

Full list of author information is available at the end of the article
}

C Biomed Central

(c) 2012 Wojcik et al; licensee BioMed Central Ltd. This is an Open Access article distributed under the terms of the Creative Commons Attribution License (http://creativecommons.org/licenses/by/2.0), which permits unrestricted use, distribution, and reproduction in any medium, provided the original work is properly cited. 
geometric structure of two-dimensional maps for phase lag between the cells. This reveals the organizing centers of emergent polyrhythmic patterns and their bifurcations, as the asymmetry of the synaptic coupling is varied. The presence of multistability and the types of attractors in the network are shown to be determined by the duty cycle of bursting, as well as coupling interactions.

\section{Acknowledgements}

We thank W. Kristan, A. Neiman, P. Ashwin, C. Laing, and R. Lin for valuable suggestions.We acknowledge support from NSF Grants CISE/CCF-0829742 (to R.C.), DMS-1009591, RFFI Grant No. 08-01-00083 (to A.S.) and "Grant opportunities for Russian scientists living abroad" Project No. 14.740.11.0919, and the GSU Brains \& Behavior program.

\section{Author details}

'Department of Mathematics and Statistics, Georgia State University, Atlanta, GA 30033, USA. ${ }^{2}$ Neuroscience Institute, Georgia State University, Atlanta, GA 30033, USA.

Published: 16 July 2012

\section{Reference}

1. Wojcik J, Clewley R, Shilnikov A: Order parameter for bursting polyrhythms in multifunctional central pattern generators. Physics Review E 2011, 83:056209-6, DOl: 10.1103/PhysRevE.83.056209.

doi:10.1186/1471-2202-13-S1-P188

Cite this article as: Wojcik et al:: Phase-lag return mappings for a 3 cell multifunctional central pattern generator. BMC Neuroscience 201213 (Suppl 1):P188.

\section{Submit your next manuscript to BioMed Central} and take full advantage of:

- Convenient online submission

- Thorough peer review

- No space constraints or color figure charges

- Immediate publication on acceptance

- Inclusion in PubMed, CAS, Scopus and Google Scholar

- Research which is freely available for redistribution

Submit your manuscript at www.biomedcentral.com/submit 